\title{
Acute Toxicity of Copper and Zinc and their Lethal Concentration on Clarias Gariepinus (Cat Fish)
}

\author{
Edeh Emmanuel Chidiebere* \\ Zhejiang Normal University, China \\ *Corresponding author: Edeh Emmanuel Chidiebere, Zhejiang Normal University, China
}

\begin{tabular}{|c|c|}
\hline ARTICLE INFO & ABSTRACT \\
\hline $\begin{array}{l}\text { Received: 梆 April 30, } 2019 \\
\text { Published: 幽 May 10, } 2019\end{array}$ & $\begin{array}{l}\text { Due to uncontrolled discharge of industrial waste into water bodies leading to eco- } \\
\text { logical risk from heavy metals, there have been increased mortality rate of aquatic lives, } \\
\text { especially in the river-line areas of Nigeria. Most commonly identified metals were copper }\end{array}$ \\
\hline $\begin{array}{l}\text { Citation: Edeh Emmanuel Chidie- } \\
\text { bere. Acute Toxicity of Copper and } \\
\text { Zinc and their Lethal Concentration on } \\
\text { Clarias Gariepinus (Cat Fish). Biomed } \\
\text { J Sci \& Tech Res 17(5)-2019. BJSTR. } \\
\text { MS.ID.003076. } \\
\text { Keywords: Clarias gariepinus; Copper } \\
\text { and Zinc; Toxicity; Lethal concentration } \\
\left(\mathrm{LC}_{50}\right)\end{array}$ & $\begin{array}{l}\text { and zinc. As a result, this study investigated Acute toxicity of copper and zinc and their } \\
\text { lethal concentration on Clarias gariepinus using the toxicity scale of } 96 \mathrm{hr} \mathrm{LC}_{50} \text { values and } \\
\text { the statistical Profit Analysis Method to determine their response to these metals. The } \\
\text { Results showed that copper and zinc accumulation in the tissues of } C \text {. gariepinus and its } \\
\text { mortality responses varied with concentration and period of exposure. copper }(40,60 \text {, } \\
80 \text { and100mg/l) and zinc }(40,60,80 \text { and } 100 \mathrm{mg} / \mathrm{l}) \text { exposed over } 96 \text {-hour } \mathrm{LC}_{50} \text { value for } \\
\text { Clarias gariepinus was found to be } 59.357 \mathrm{mg} / \mathrm{l} \text { for copper and } 65.151 \mathrm{mg} / \mathrm{l} \text { for zinc respec- } \\
\text { tively. Control mortality was however at } 5 \% \text {. At } 95 \% \text { lower and upper confidence limits } \\
\text { for copper, the } \mathrm{LC}_{50} \text { values were } 44.394 \text { and } 67.848 \mathrm{mg} / \mathrm{l} \text {, while zinc was } 36.3 \text { and } 75.36 \\
\text { mg/l respectively. The result suggested that copper and zinc as common constituent in } \\
\text { industrial wastes discharged into water bodies possess possible ecological risk to marine } \\
\text { lives especially at high concentrations, therefore, it is important that the usage of these } \\
\text { heavy metals are controlled. }\end{array}$ \\
\hline
\end{tabular}

\section{Introduction}

Fish are particularly vulnerable and heavily exposed to pollution in their aquatic environments where they live and feed, because they can hardly escape from the detrimental effects of pollutants [1,2]. In comparison with invertebrates, Fish are convenient test subject for indication of ecosystem health as they show higher sensitivity to many toxicant [3-6]. Owing to this, Fish are considered to be most significant bio-monitors in aquatic ecosystem for the estimation of metal pollution level [7-8]. They offer several specific advantages in describing the natural characteristics of aquatic system and in assessing changes to habitats [9]. In addition, fish are located at the end of the aquatic food chain and may accumulate metals and possibly pass them to human beings through food causing chronic or acute disease [10].

Heavy metal pollution In aquatic environment, often results from direct atmospheric deposition, geological weathering or through the discharge of agricultural, municipal, residential or industrial waste products, and also through waste water treatment plants [11-14] for instance, Coal combustion is one of the most important anthropogenic emission sources of trace elements and an important source of a number of metals [15,16] noted that Increasing human population, rapid industrialization and commercial activities in Onitsha metropolis and the resultant continuous discharge of domestic and industrial effluents into the Niger river accounts for the increase in concentration of heavy metal in the river. which also resulted in bioaccumulation of heavy metals in the fish macro bacterium Rosenberg caught in the river [17]. Heavy metals pollution is one of the five major types of toxic pollutants commonly present in surface and ground waters [18]. Fish accumulate pollutants preferentially in their fatty tissues like liver and the effects become apparent when concentration in such tissues attain a threshold level [19].

However, this accumulation depends upon their intake, storage and elimination from the body [20]. This means that metals with high uptake and low elimination rates in tissues of fish are expected to be accumulated to higher levels $[21,22]$. Heavy metals can be taken up into fish either from ingestion of contaminated food via the 
alimentary canal or through the gills and skin [23,24]. Effectively after the absorption, metals in fish are then transported through blood stream to the organs \& tissues where they are accumulated $[25,26]$. Many factors can affect or modify the degree of sensitivity shown by an organism to different toxicants. Some examples are the specific diet, season of the year, and water quality variables such as temperature, ph, and hardness [27]. Since fish are poikilothermic, temperature is one of the most important environmental factors controlling biological rates, and therefore would be expected to influence tissue uptake of metals as well as the toxicity tolerance in fish [28]. An increase in water temperature will increase the rate of chemical reactions in fish as predicted by the Arrhenius theory [29]. This theory also predicts that the toxicity of a metal also increases with a rise in temperature as reported during exposure of Tilapia zilli and Clarias lazera [30].

The calcium content (hardness) of water acts as a modifying factor with an increase in metal toxicity in water with a low calcium content $[31,32]$. The toxicity of pollutants may be increased by a reduction in dissolved oxygen [33] whilst the hydrogen ion concentration (ph.) can affect the ionization and the solubility of the metal [34]. The toxicity of metals causes negative biological effects on survival, activity, growth, metabolism, or reproduction of many species. Symptoms of metal poisoning typically include hyperactivity followed by sluggishness before death, swimming at the surface, lethargic and uncoordinated movements hemorrhage at gills and base of fins, shed scales, and extensive body and gill mucus [35]. Element which are essential under normal circumstances, such as copper, and zinc may become pollutant when excessive amount is present and exhibit toxic effect on organisms. Therefore, the establishment of critical concentration of these elements in aquatic systems, whether natural or man-made, by bio-assay techniques (toxicity tests) is necessary in determining acceptable levels of pollution [36]. Ecological needs, size and age of individuals, their life cycle, feeding habits and the season of capture were also found to affect experimental results from the tissues [37-39].

There have been numerous studies on the toxicity of heavy metals (copper and zinc) and their lethal influence in aquatic ecosystem. Abadi et al. [40] noted that Copper (cu), and Zinc (zn), are essential metals with known important biological roles. Their toxicity occurs either at metabolic deficiencies or at high concentration [41] and the form in which they occur in water influences their toxicity to fish. for instance, the ionic forms of metals or simple inorganic compounds are more toxic than complex inorganic or organic compounds. The toxicity of copper and zinc to aquatic life varies with the physical and chemical conditions of the water. Factors like water hardness, alkalinity, ph., dissolved oxygen and temperature affect the toxicity of copper and zinc $[34,42,43]$.

There are also, marked differences in copper and zinc sensitivity among species. For instance, [44] reported that copper was significantly more toxic to Oreochromis niloticus than the Clarias gariepinus, the $96 \mathrm{hrs} \mathrm{LC}_{50}$ values for Oreochromis niloticus and Clarias gariepinus were revealed to be $58.837 \mathrm{mg} / \mathrm{l}$ and $70.135 \mathrm{mg} / \mathrm{l}$ respectively. Also, high concentration of copper has been reported to inhibit catalase enzyme in liver, gill and muscle after $24 \mathrm{hrs}$ of exposure in Cyprinus carpio [45]. On the other hand, spear (1981) reported that the order perciforms were found to be more resistant while clupeiforms are more sensitive to zinc. According to Cusimano et al. [43] Salmonid fishes were found to be highly susceptible

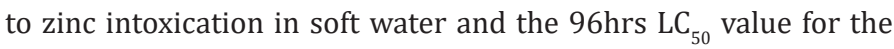
rainbow trout was found to be $0.066 \mathrm{mg} / \mathrm{l}$. However, Sobbe and De (1974) noted that the value goes up to 2.5 to $4.7 \mathrm{mg} / \mathrm{l}$ in very hard water.

Non-salmonid fish on the other hand are known to be less sensitive than salmonid fish. Khangarot et al. [46] noted $96 \mathrm{hrs} \mathrm{LC}_{50}$ for common carp in soft water to be $3.12 \mathrm{mg} / \mathrm{l}$. The main target of water borne copper and zinc toxicity are the gills, kidney, liver and skeletal muscles $[46,47]$. Copper induced histological alterations are found in the gill, kidney hematopoietic tissues, mechanoreceptors, chemo receptors, and other tissues Sorensen (1991). Higher doses of copper caused visible external lesions such as discoloration and necroses on livers of Cyprinus carpi, Corassius auratus and Corydoras paleatus [48]. Clarke et al. (1981) reported that zinc toxicity disrupts the $\mathrm{ca}^{2+}$ uptake in the gills, leading to hypocalcaemia and eventually death [49]. Copper and Zinc toxicity are known to impair growth, reproduction, hatching, reduced survival of young, and other effect in fish [50,51]. On the combined effect of Copper and Zinc, Obiakor et al. [44] evaluated the genotoxicity of copper, and zinc and their binary mixture on Synodontis clarias and Tilapia nilotica using micronucleus test in fish genome.

The authors documented elevated micronuclei frequency following exposure to highest and lowest concentration of binary mixture of the heavy metals on the fish species at $96 \mathrm{hrs} \mathrm{LC}_{50}$. Hilmy et al. [30] reported that the acute toxicity to juvenile Clarias lazera of a mixture of copper and zinc over a 96hrs exposure period showed The comparison between metal residue in fish that the uptake of one metal was decrease by the presence of the other, Copper had more toxic effect than zinc. The importance of modifying factors cannot be overestimated, as many records of their influence on the variation in toxicity can be found in the literature, however it is vital to determine the specific $\mathrm{LC}_{50}$ value (Lethal Concentration for $50 \%$ of the test organism) for a given combination of abiotic conditions. The study reported here was carried out to determine the acute toxicity and $96 \mathrm{hrs}$ lethal threshold concentration or incipient $\mathrm{LC}_{50}$ values of copper and zinc at the selected temperature of $25 \pm 2^{\circ} \mathrm{C}$ for fingerling of Clarias gariepinus. The lethal threshold concentration is usually defined as that concentration which causes death to half the test organisms with a specified period of time. eg 96hrs [52].

\section{Materials and Method}

150 Clarias gariepinus fingerlings were obtained from a local fish farm in awka, Anambra State. They were placed in five plastic 
aquaria filled with underground well water. The aquaria were covered with net to prevent escape of the fish. The fish were fed after $24 \mathrm{hrs}$ of arrival with commercial feed. They acclimated to the experimental site condition for 12 days at the selected temperature of $25 \pm 2^{\circ} \mathrm{C}$. The mean initial weight of each fish was $4 \mathrm{~g} \pm 2$ and the length were $8.5 \mathrm{~cm} \pm 1.5$. Underground well water was used for this experiment. The water was obtained from an underground well at the Animal and Fishery unit, Nnamdi Azikiwe University, Awka. Water quality parameters such as temperature, dissolved oxygen, $\mathrm{pH}$, and hardness were measured before the commencement of the study. The compounds used in the experiment were copper sulphate $\left(\mathrm{CuSO}_{4}\right)$ and zinc sulphate $\left(\mathrm{ZnSO}_{4}\right)$ salt. The salt of zinc and copper dissolved separately in water were used as toxicant. The test organisms were subjected to different concentrations $(40,60$, $80,100 \mathrm{mg} / \mathrm{l}$ ) of the zinc sulphate and copper sulphate respectively. The volume of each aquarium was measured before the calculated concentrations of zinc salt and copper salt were added.

The acclimated fish were not fed $24 \mathrm{~h}$ before the start of the tests. Also, the fish were not fed during the course of the experiment. The experiment lasted for $96 \mathrm{~h}$, the number of dead fishes were counted every $24 \mathrm{~h}$ and were removed as fast as possible. The fish became dead when it was motionless and sank to the bottom of the aquarium. The mortality rate was determined at the end of 96hrs. Simultaneously the control group was kept in the experi- mental water. There was no addition of copper salt and zinc salt to the group. The mortality on the control did not exceed 5\%. The fish were in good condition except for a slight decrease in weight. Mixed concentration of copper and zinc were also tested to know the toxicity difference between the two salts. This was done by addition of $1 / 10$ (one tenth) the $\mathrm{LC}_{50}$ (lethal concentration) of the two salt respectively. The procure was carried out as described by 1993, OECD and Standard Methods for the Examination of Water and Wastewater, 1971. Assessment of mortality (quantal response) determined at the end of the 96th hour as a result of toxicity of zinc and copper on the test animals (Clarias gariepinus) was determined by the use of Finney's Probit Analysis LC $_{50}$ Determination Method [53].

\section{Results}

Table 1 shows the physio-chemical characteristic variables maintained in the aquaria for the toxicity testing of the fish species, while Tables $2 \& 5$ gives the relationship between the different exposure concentrations and the mortality response rate of Clarias gariepinus. The Probit parametric estimates and the obtained results for the acute static 96-hour toxicity estimated lethal concentration values and their confidence limits are shown in Tables 3,4,6 \& 7 respectively. Figure $1 \& 2$ displays the probit line graph of acute toxicity of copper and zinc respectively for Clarias gariepinus and Table 7 showing the 96hrs acute toxicity of copper and Zinc on Clarias gariepinus.

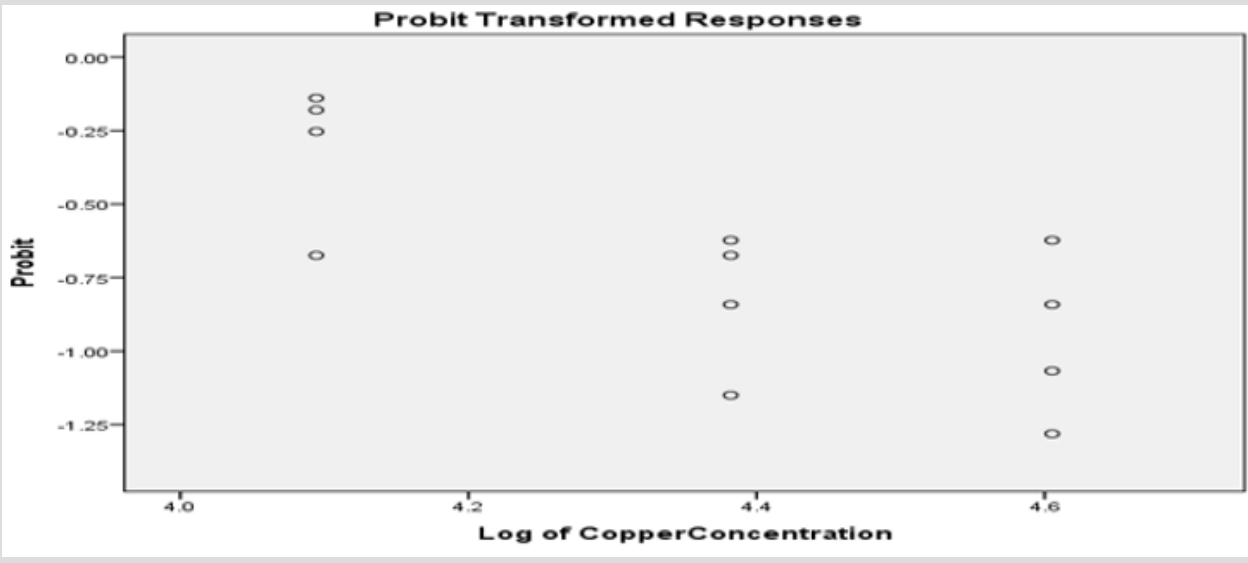

Figure 1: Probit line graph of acute toxicity of Copper on Catfish.

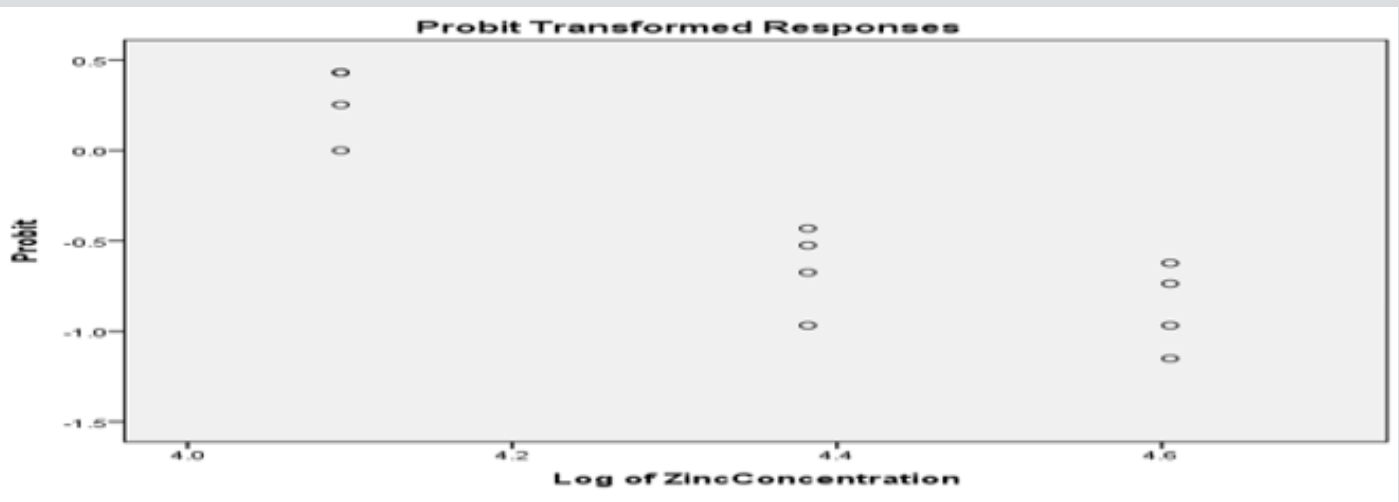

Figure 2: Probit line graph of acute toxicity of Zinc on Catfish. 
Table 1: Temperature, Dissolved Oxygen and $\mathrm{pH}$ of the aquaria used in the study.

\begin{tabular}{|c|c|c|c|}
\hline Concentration & Temperature(0C) & Dissolved Oxygen & Ph \\
\hline 40 & 26.49 & 7.02 & 6.35 \\
\hline 60 & 26.26 & 7.02 & 6.35 \\
\hline 80 & 26.26 & 7.02 & 6.35 \\
\hline 100 & 26.27 & 7.02 & 6.35 \\
\hline Control & 26.48 & 7.02 & 6.35 \\
\hline Mean & $26.35 \pm 1.09$ & $7.02 \pm 0.55$ & $6.35 \pm 0.55$ \\
\hline
\end{tabular}

Table 2: The relationship between the zinc concentration and the mortality rate of Clarias gariepinus [54] for the 96-hour exposure.

\begin{tabular}{|c|c|c|c|c|c|}
\hline \multirow{2}{*}{ Conc.(mg/l) } & \multirow{2}{*}{ No. of Test Animal } & \multicolumn{4}{|c|}{ Period of Exposure } \\
\hline & & $24 \mathrm{hr}$ & $48 \mathrm{hr}$ & $72 \mathrm{hr}$ & 96hr \\
\hline 40 & 15 & 0 & 1 & 2 & 2 \\
\hline 60 & 15 & 2 & 3 & 5 & 6 \\
\hline 80 & 15 & 6 & 8 & 10 & 12 \\
\hline 100 & 15 & 8 & 12 & 13 & 15 \\
\hline 0 (Control) & 15 & 0 & 0 & 1 & 0 \\
\hline
\end{tabular}

Table 3: Parameter Estimates for the Probit Analysis.

\begin{tabular}{|c|c|c|c|c|c|c|c|}
\hline \multicolumn{8}{|c|}{ Parameter Estimates } \\
\hline & \multirow{2}{*}{ Parameter } & \multirow{2}{*}{ Estimate } & \multirow{2}{*}{ Std. Error } & \multirow{2}{*}{$\mathbf{Z}$} & \multirow{2}{*}{ Sig. } & \multicolumn{2}{|c|}{ 95\% Confidence Interval } \\
\hline & & & & & & Lower Bound & Upper Bound \\
\hline \multirow{2}{*}{ PROBIT ${ }^{\mathrm{a}}$} & Zinc Concentration & -2.082 & 0.728 & -2.859 & 0.004 & -3.51 & -0.655 \\
\hline & Intercept & 8.696 & 3.225 & 2.696 & 0.007 & 5.471 & 11.921 \\
\hline
\end{tabular}

a. PROBIT model: PROBIT (p) = Intercept + BX (Covariates X are transformed using the base 2.718 logarithm).

Table 4: The relationship between the copper concentration and the mortality rate of Clarias gariepinus [54] for the 96-hour exposure.

\begin{tabular}{|c|c|c|c|c|c|}
\hline \multirow{2}{*}{ Conc.(mg/l) } & \multirow{2}{*}{ No. of Test Animal } & \multicolumn{4}{|c|}{ Period of Exposure } \\
\hline & & $24 \mathrm{hr}$ & $48 \mathrm{hr}$ & $72 \mathrm{hr}$ & $96 \mathrm{hr}$ \\
\hline 40 & 15 & 1 & 1 & 3 & 4 \\
\hline 60 & 15 & 4 & 5 & 7 & 9 \\
\hline 80 & 15 & 8 & 10 & 12 & 15 \\
\hline 100 & 15 & 10 & 14 & 15 & 15 \\
\hline 0 (Control) & 15 & 0 & 0 & 0 & 0 \\
\hline
\end{tabular}

Table 5: Parameter Estimates for the Probit Analysis.

\begin{tabular}{|c|c|c|c|c|c|c|c|}
\hline \multicolumn{8}{|c|}{ Parameter Estimates } \\
\hline & \multirow{2}{*}{ Parameter } & \multirow{2}{*}{ Estimate } & \multirow{2}{*}{ Std. Error } & \multirow{2}{*}{$\mathbf{Z}$} & \multirow{2}{*}{ Sig. } & \multicolumn{2}{|c|}{ 95\% Confidence Interval } \\
\hline & & & & & & Lower Bound & Upper Bound \\
\hline \multirow{2}{*}{ PROBIT $^{\mathrm{a}}$} & $\begin{array}{c}\text { Copper } \\
\text { Concentration }\end{array}$ & -4.734 & 1.14 & -4.151 & 0 & -6.969 & -2.498 \\
\hline & Intercept & 8.395 & 2.161 & 3.884 & 0 & 6.234 & 10.556 \\
\hline
\end{tabular}

a. PROBIT model: PROBIT $(\mathrm{p})=$ Intercept + BX (Covariates $X$ are transformed using the base 10.000 logarithm).

Table 6: 96hrs acute toxicity of Zinc and copper on Clarias gariepinus [54].

\begin{tabular}{|c|c|c|c|c|c|}
\hline \multirow{2}{*}{ Test Animal } & & LC5 & LC50 & LC95 & S.E \\
\hline \multirow{2}{*}{ Clarias gariepinus } & Copper & 132.113 & 59.357 & 26.668 & 1.14 \\
\cline { 2 - 6 } & Zinc & 143.556 & 65.151 & 29.568 & 0.728 \\
\hline
\end{tabular}

Table 7: The relationship between the 1/10 zinc and copper concentration and the mortality rate of Clarias gariepinus [54] for the 96hour exposure.

\begin{tabular}{|c|c|c|c|c|c|}
\hline \multirow{2}{*}{ Conc.(mg/l) } & \multirow{2}{*}{ No. of Test Animal } & \multicolumn{4}{|c|}{ Period of Exposure } \\
\cline { 3 - 6 } & & $\mathbf{2 4 h r}$ & $\mathbf{4 8 h r}$ & $\mathbf{7 2 h r}$ & 1 \\
\hline 0.0125 & 15 & 0 & 0 & $\mathbf{9 6 h r}$ \\
\hline
\end{tabular}




\section{Physical Parameters of Well Water in the Aquaria Used for the Study}

From the results of the Physio-chemical parameters measured and presented in table above, water temperature was recorded to be $26.35 \pm 1.09^{\circ} \mathrm{C}$; the dissolved oxygen concentration was $7.02 \pm$ $0.55 \mathrm{mg} / \mathrm{l}$, while the ph was $6.35 \pm 0.55$ (Table 1).

The Relationship Between the Zinc Concentration and the Mortality Rate of Clarias Gariepinus for the 96-Hour Exposure

(Tables 2 \& 3).

The Relationship Between the Copper Concentration and the Mortality Rate of Clarias Gariepinus for the 96Hour Exposure

(Tables 4-6) (Figures 1 \& 2).

The Relationship Between the 1/10 Zinc and Copper Concentration and the Mortality Rate of Clarias Gariepinus for the 96-Hour Exposure

(Table 7).

\section{Discussion}

The Finney's probit analysis method was used to investigate 96-hour LC $_{50}$ value for Clarias gariepinus exposed to different concentrations (40,60, 80 and 100mg) for copper and Zinc respectively. Control mortality was however at 5\%. 95\% lower and upper confidence limits for the $\mathrm{LC}_{50}$ values were 44.394 and 67.848 $\mathrm{mg} / \mathrm{l}$ for copper, while 36.3 and $75.36 \mathrm{mg} / \mathrm{l}$ respectively were for zinc. These toxic effects of copper and zinc increased, (Table 2) (Figure 2) for zinc and (Table 4) (Figure 1) for copper as their concentrations were increased. Several factors such as the type of the tested heavy metal, solubility of the chemical characteristics of the test solution and the mechanism of action of the different metals, contributed to the different toxicity observed in tested metals which is also found to concur with the findings of [54]. All these factors determined the availability and penetrability of the metals into the test animals and hence, their toxicity. While working on the toxicity testing of Poecilia reticulatata in hard water (260mg $\mathrm{CaCO}_{3} / \mathrm{L}$ ) [55] reported the $96-\mathrm{h} \mathrm{LC}_{50}$ value to be $55 \mathrm{mg} / \mathrm{L}$. Although this result is slightly lower to our observations in Clarias gariepinus (59.357 for copper and $65.151 \mathrm{mg} / \mathrm{L}$ for zinc-Table 7 ). The difference could be attributed to variations physio-chemical properties (Table 1), which had already been documented.

From the study, it was observed that the test organisms became irritable over a period of time, but more erratic display were observed with increased concentration of the metals. The fish were seen swimming to the surface frequently with their opercula and mouths moving rapidly an indication that the Toxic effect of the heavy metals caused the depletion of the oxygen content of the medium. swimming Activity and frequent surfacing reduced drastically, color change from black to pale with mucus covering the body were observed. The mucus covering the entire body of the test organisms might have resulted from response to the toxic effect of the heavy metals through excretion of some accumulated metals in their tissues. Khalaf et al. [56] \& Heath [30], supported this observation that the skin is an important excretory organ for heavy metals. Consequently, the age of the fish could also influence its response to a given contaminant or toxicant in a given medium as reported by [57]. Findings from this study on binary combination of the heavy metals is consistent with the observations of Hilmy et al. [30] who reported that copper was significantly more toxic than zinc for the $96 \mathrm{hrs} \mathrm{LC}_{50}$ exposure with Clarias lazera [58-67].

\section{Conclusion}

From the present study, it can be stated conclusively that fish has the tendency to accumulate heavy metals in a polluted environment. Lethal effects of zinc and copper have been widely reported for different aquatic organisms and their exposure methods. Since these metals are an important constituent of industrial wastes discharged into water bodies, there is need to regulate the use of this heavy metal (zinc and copper) to prevent future damages in aquatic environment. Further study of toxicity testing methods on fish both in laboratory and in its immediate natural environment will be very useful in assessing possible ecological risk of heavy metals.

\section{References}

1. Yarsan E, Yipel M (2013) The important terms of marine pollution bio makers and bio monitoring, bio accumulation, Bio Concentration, Bio Magnification. J Molecular Bio Marker Diagnosis p. S1.

2. Saleh YS, Marie MAS (2014) Assessment of Metal Contamination in Water Sediment, and Tissues of Arius Thalassinus Fish from the Red Sea Coast of Yemen and the Potential Human Risk Assessment. Environmental Science Pollutant Research 22(7): 5481-5490.

3. Adams SM, Ryon MGA (1994) A Comparison of Health Assessment Approaches for Evaluating the Effects of Contaminant Related Stress on Fish Populations. J Aquatic Ecosystem Health 3(1): 15-25.

4. Whitfield AK, Elliott M (2002) Fishes as Indicators of Environmental and Ecological Changes Within Estuaries: A Review of Progress and Some Suggestions for The Future. J Fish Biology 61(sA): 229-250.

5. Khallaf EA, Gala M, Authman M (2003) The Biology of Oreochromis Niloticus In A Polluted Canal. Ecotoxicology 12(5): 405-416.

6. Zaki MS, Authman MMN, Hamman AMM, Shalabym SI (2014) Aquatic Environmental Pollution in the Egyptian Countryside and its Effects on Fish Production (Review). Life Science Journal 11(9): 1024-1029.

7. Rashed M (2001) Monitoring of Environmental Heavy Metals in Fish from Nasser Lake. Environmental Interaction 27(1): 27-33.

8. Authman MMN (2008) Oreochromis Niloticus as a Bio Monitor of Heavy Metalpollution with Emphasis on Potential Risk and Relation to Some Biological Aspects. Global Veterinary 2(3): 104-109.

9. Lamas S, Fernandez JA, Aboal JR, Carballeira A (2007) Testing the Use of Juvenile Salmo trutta L. as Bio Monitors of Heavy Metal Pollution in Fresh Water. Chemosphere 67(2): 221-228.

10. Al Yousuf MH, El Shahawi MS, Al Ghais SM (2000) Trace Metals in the Liver, Skin and Muscle of Lethrinus Lentian Fish Species in Relation to Body Length and Sex. Science of Total Environment 256(2-3): 87-94.

11. Demirak A, Yilimaz F, Levent Tuna A, Ozdemir N (2006) Heavy Metals in Water, Sediment and Tissues of Lenciscus Cephlaus From A Stream in South Western Turkey. Chemosphere 63(9): 1451-1458. 
12. Maier D, Biaha L, Giesy JP, Hennebergy A, Kohler HR, et al. (2014) Biological Plausibility as a Tool to Associate Analytical Data from Micro Pollutants and Effect Potentials in Waste Water, Surface Water and Sediments with Effects in Fishes. Water Research 72(1): 127-144.

13. Dhanakumar S, Solaraj G, Moharaj R (2015) Heavy Metal Partitioning in Sediments and Bio Accumulation in Commercial Fish Species of Three Major Reservoirs of River Cauvery Delta Region, India. Eco Toxicology Environmental Safety 113: 145-151.

14. Garcia JC, Martinez DST, Alves Ol, Leonardo AFG, Barbieri E(2015) Eco Toxicological Effects of Carbofuran And Oxidized Multi Walled Carbon Nano Tubes on The Fresh Water Fish, Nile Tilapia: Nano Tubes Enhance Pesticide Eco Toxicity. Eco Toxicology Environmental Safety 111: 131137.

15. Wager A, Boman J (2003) Bio Monitoring of Trace Elements in Muscle and Liver Tissues of Fresh Water Fish. Spectorchim ACTA B 58(12): 2215-2226

16. Nsofor CI, Aguiwo JN (2005) The Bio Accumulation of Zinc, Iron, Copper, Lead, And Cadmium by Some Fish Species from The River Niger, Anambra State. Environmental Study research Journal 5: 122-129.

17. Nsofor CI, IO Ikpeze, Ikeogu CF, Umeoguagu FO, Okonkwo CJ (2014) Bio Accumulation of Heavy Metals in Shellfish Macrobacterium Rosenbergi In River Niger At Onitsha, Anambra State, Nigeria. International Journal of Agric Bio Science 3(1): 38-40.

18. Merian E (1991) Metals and their Compounds in the Environment Occurrence Analysis and Biological Relevance. pp. 1438.

19. Omar WA, Saleh YS, Marie MAS (2014) Integrating Multiple Fish Biomarkers and Risk Assessment as Indicators of Metal Pollution Along the Red Sea Coast of Hodeida, Yemen Republic. Eco Toxicology Environment SAF 110: 221-231.

20. Abdallah MAM, Morsy FAE (2013) Persistent Organ Chlorine Pollutants and Metals Residues in Sediment and Fresh Water Fish Species Cultured in a Shallow Lagoon, Egypt. Environmental Technology 34(16): 23892399.

21. Kalay M, Canli M (2000) Elimination of Essential (Cu, Zn) And NonEssential (Cd, Pb) Metals from Tissues of a Fresh Water Fish Tilapia Zilli Turkey Zoology 24: 429-436.

22. Idriss AA, Ahmad AK (2015) Heavy Metal Concentrations in Fishes from Juru River, Estimation of The Health Risk. Bulletin. Environmental Contamination Toxicology 94(2): 204-208.

23. Drevnick PE, Sandheinrich MB, Oris JT (2006) Increase Ovarian Follicular Apoptosis in Fathead Minnows (Pimephale Promelas) Exposed to Dietary Methymercury. Aquatic Toxicology 79(1): 49-54.

24. Sfakianakis DG, Renieri E, Kentouri M, Tsatsakis AM (2015) Effect of Heavy Metals on Fish Larvae Deformities: A Review. Environmental Research 137: 246-255.

25. Adeyemo OK, Adedeji OB, Offor CC (2010) Blood Lead Level as Bio Marker of Environmental Lead Pollution in Feral and Cultured African Catfish (Claria Gariepinus). Nigeria Veterinary Journal 31(2): 139-147.

26. Fazio F, Piccione G, Tribulato K, Ferrantelli V, Giangrosso G, et al. (2014) Bio Accumulation of Heavy Metals in Blood and Tissues of Striped Mullet in Two Italian Lakes. Aquatic Animal Health 26(4): 278-284

27. Falk Dl, WA Dunston (1977) The Effects of Season and Acute Sub Letha Exposure on Survival Time of Book Trout at Low Ph. Water Research 11(1): 13-15.

28. Smith MJ, Heath AG (1979) Acute Toxicity of Copper, Chromate, Zinc, And Cyanide to Fresh Water Fish: Effects of Different Temperature. Bulletin of Environmental Contaminant Toxicology 22(1): 113-119.

29. Eddy FB (1981) Effects of Stress on Osmotic and Ionic Regulation in Fish. Stress and Fish. (edn.). AD. Pickering Academic Press. London, UK, pp. 77-102.

30. Hilmy AM, ElDominaty NA, Daabees AY, and Abdellatife HA (1987) Toxicity in Tilapia Zilli and Clarias Lazera Induced by Zinc, Seasonally. Comp BioChem Physio 86(2): 263-265.
31. Gregory P, Macfarlane NAA (1981) Surface Permeability in Fish: Effects of External Calcium and Toxicant Action. In: Stress and Fish (edn.). AD Pickering Academic Press, London pp. 343-344.

32. Lloyd R (1992) Pollution and Fress Water Fish. Fishing News Books. A Division of Black Well Scientific Publications Ltd, Great Britain pp. 176.

33. Lloyd R (1961) The Toxicity of Copper and Zinc Sulphates to South African Fish. Wildlife Research 26(2).

34. Bradley RW, JB Spragne (1985) The Influence of Ph, Water Hardness, and Alkalinity on the Acute Lethality of Zinc on Rainbow Trout (Salmo Gairgneri), Canada. Journal of Fish Aquatic Science 42(4): 731-736.

35. Bengeri KV, Patial HS (1986) Respiration, Liver Glycogen and Bio Accumulation in Labeo Rohita Exposed to Zinc. Indian Journal. Comprehensive Animal Physiology 4: 79-84.

36. Gail Nussey, JHJ Vanvuren, HH Dupreez (1996) Acute Toxicity Tests of Copper on Juvenile Mozambique Tilapia, O Mossambicus (Cichlidae), at Different Temperature. S Africa Wildlife Research 26(2): 47-55.

37. Kime DE, Ebrahimi M, Nysten K, Roelants I, Rurangwa E, et al. (1996) Use of Computer Assisted Sperm Analysis (CASA) For Monitoring the Effects of Pollution on Sperm Quality of Fish: Application to the Effects of Heavy Metal. Aquatic Toxicology 36(3-4): 223-237.

38. Rurangwa E, Roelants I, Huyskens G, Ebrahimi M, Kime DE, et al. (1998) The Minimum Effective Spermatozoa: Egg Ratio for Artificial I9nsemination And the Effects of Mercury on Sperm Motility and Fertilization Ability in Clarias Gariepinus. Fish Biology 53(2): 402-413.

39. Onen SA, Kucuksezgin F, Kocak F, Acik S (2015) Assessment of Heavy Metal Contamination in Hediste Diversicolor (O.F. Muller, 1776), Mugil Cephalus (LINNAEUS, 1758) and Surface Sediments of Bafa Lake (Eastern Aegean). Environ Sci Pollut Res Int 22(11): 8702-8718.

40. Abadi DRV, Dobaradaran S, Nabipour I, Lamani X, Ravanipour M, et al. (2014) Comparative investigation of heavy metal, trace and macro element contents in commercially valuable fish species harvested off from the person gulf. Environ Sci Pollut Res Int 22(9): 6670-6678.

41. Sivaperumal P, Sankar TV, Viswanathan, Nair PG (2007) Heavy Metal Concentrations in Fish, Shellfish and Fish Products from Internal Markets of India Vis -A-Vis International Standards. Food Chemistry 102(3): 612-620.

42. Holcombe GW, RW Andrew (1978) The Acute Toxicity of Zinc to Rainbow and Brook Trout: Comparison in Hard and Soft Water. USEPA pp. 1-16.

43. Cusimano RF, DF Brake, GA Chapman (1986) Effects of Ph on the Toxicities of Cadmium, Copper and Zinc to Steelhead Trout (Salmo Gairdneri),Canada. J Aquqtic Science 43(8): 1497-1503.

44. Ezeonyejiaku CD, Obiakor MO, Ezenwelu CO (2011) Toxicity of Copper Sulphate and Behavioral Locomotor Response of Tilapia (Oreochromis Niloticus) And Catfish (Clarias Gariepinus) Species. Online Journal of Animal and Feed Research 1(4): 130-134.

45. Radi AAR, Matkovics B (1988) Effects of Metal Ions on The Antioxidant Enzyme Activities, Protein Contents and Lipid Per Oxidation of Carp Tissues. Comprehensive Biochemical Physiology C 90(1): 69-72.

46. Khangorot MBS, A Sehgal, MK Bhasin (1983) Man, and BiosphereStudies on Sikkim Hilmalayas, PART 1: Acute Toxicity of Copper and Zinc to Common Carp Cyprinus Carpio (Linn.) In Soft Water, Acta Hydrochim. Hydro Biology 11(6): 667-673.

47. Jezierska B, Witeska M (2006) The Metal Uptake and Accumulation in Fish Living in Polluted Waters. Soil and Water Pollution Monitoring, Protection and Remediation pp. 107-114.

48. Cavas T, Garanko NN, Arkhipchuk W (2005) Induction of Micronuclei and Binuclei In Blood, Gill and Liver Cells of Fishes Sub Chronically Exposed to Cadmium Chloride and Copper Sulphate. Food Chemical Toxicology 43(4): 569-574

49. Niyogi S, Wood CM (2006) Interaction Between Dietary Calcium Supplementation and Chronic Water Borne Zinc Exposure in Juvenile Rainbow Trout, Oncorhynchus Mykiss. Comprehensive Biochemical Physiology C 143(1): 94-102. 
50. Nussey G ,Van Vuren JHJ, Dupreez HH (1995) Effects of Copper on The Hematology and Osmo Regulation of The Mozambicus tilapia, Oreochromis mossambicus (Cichlidae). Comprehensive Biochemical Physiology C 111(3): 369-380.

51. Bieniarz K, P Epler, M Sokolowska Mikolajczyk and W Popek (1997) Reproduction of Fish in Conditions Disadvantageously Altered with Salts of Zinc and Copper. Archiwum Pybactwa Polskiego 5(1): 21-30.

52. Heath Ag (1987) Water Pollution and Fish Physiology, Florida: CRC Press Inc.

53. Standard Methods for the Examination of Water and Wastewater (1971) APHA (American Public Health association), AWWA (American Water Works Association), WPCP (Water Pollution Control Program), Washington DC, USA.

54. Ezeonyejiaku CD, Obiakor MO, Ezenwelu CO, Ugochukwu GC (2010) Lethal Influence of Zinc Exposure to Clarias gariepinus (Burchell, 1822, Pisces, Clariidae). World Journal of Fish and Marine Sciences 2 (5): 455460.

55. Khangarot BS (1981) Lethal effects of zinc and nickel on fresh water teleost, Acta Hydrodium. Hydrobiology 9: 297-302.

56. Khalaf AN, AL Jafery A, Khalid BY, Elias SS, Ishaq MW (1985) The patterns of accumulation of some heavy metals in Barbus grypus from a polluted river. JBSR 16(2): 51-74.

57. Obiakor MO, JC Okonkwo, CD Ezeonyejiaku, CO Ezenwelu (2010) Genotoxicology: single and joint action of copper and zinc on Synodontis clarias and Tilapia nilotica. J Applied Science and Environmental Management 14(3): 59-64.

58. Celik U, Oehlenschlager J (2004) Determination of Zinc and Copper in Fish Samples Collected from North East Atlantic by DPSAV. Food Chemistry 87(3): 343-347

\section{ISSN: 2574-1241}

DOI: 10.26717/BJSTR.2019.17.003076

Edeh Emmanuel Chidiebere. Biomed J Sci \& Tech Res

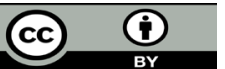

This work is licensed under Creative

Commons Attribution 4.0 License

Submission Link: https://biomedres.us/submit-manuscript.php
59. Micheal P (1984) Ecological Methods for Field and Laboratory Investigations. TATA Mcgraw- Hill Publishing Company Ltd, New Delhi, India.

60. Monteiro SM, Dos Santos NMS, Calejo M, Fontainhas Fernandes A, Souse M (2009b) Copper Toxicity in Gills of The Teleost Fish, Oreochromis Niloticus: Effects in Apoptosis Induction and Cell Proliferation. Aquatic Toxicology 94(3): 219-228.

61. Nemcsok JK, Benedeczky L, Boross L, Asztalos B, Orban L (1981) Sub Cellular Localization of Transaminases Enzyme in Fishes and Their Significance in The Detection of Water Pollution. Acta Biology Zseged 27(1-4): 9-15.

62. OECD (Organization for Economic Co-operation and Development) (1993) OECD Guidelines for testing of chemicals, OECD, Paris.

63. Shiau SY, Ning YC (2003) Estimation of Dietary Copper Requirements of Juvenile Tilapia, Oreochromis Niloticus $\times 0$. Aureus. Animal Science 77(2): 287-292.

64. Solbe JF, LG De (1974) The Toxicity of Zinc Sulphate to Rainbow Trout in Very Hard Water. Water Research 8(6): 389-391.

65. Spear PA (1981) Zinc in Aquatic Environment: Chemistry, Distribution and Toxicology, National Research Council of Canada. Environmental Secretariat Publication, Ottawa.

66. Sprague JB (1985) Factors That Modify Toxicity in Fundamental of Aquatic Toxicology: Method and Application, (Eds.) GMR, SR Petrocelli. Hemisphere Publishing Corporation, New York, USA, pp. 124-163.

67. Svobodova Z, Lloyd R, Máchová J, Vykusová B (1993) Water Quality and Fish Health 54: 67.

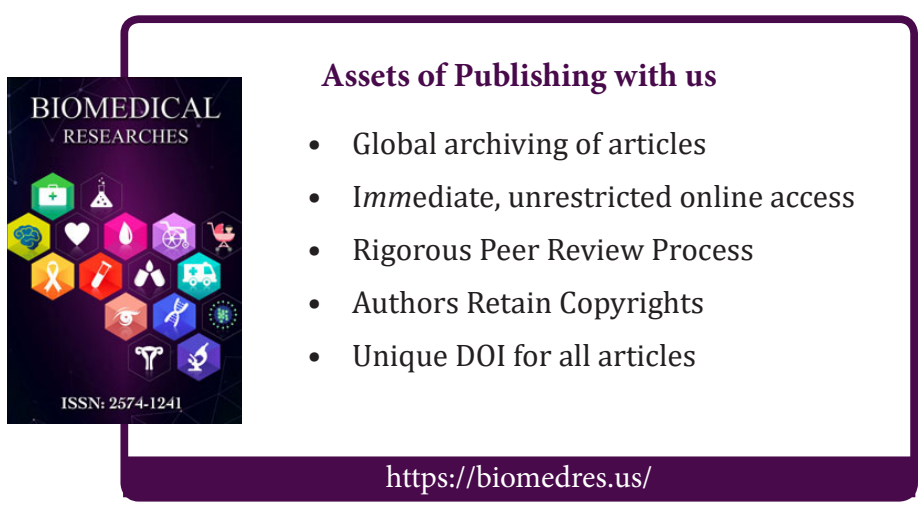

